\title{
Mineral reconnaissance of the Thule district, North-West Greenland
}

\author{
H. R. Cooke
}

In 1975 and 1977 field investigations of various possible commercial mineral deposits in North-West Greenland were carried out, with particular emphasis on an evaluation of the ilmenite-bearing beach sands. The earliest known notice of these was in 1916 when Lauge Koch sampled 'jærnsand' at 'Itivdlerk', which was found to be high-grade ilmenite sand (Ghisler \& Thomsen, 1973). The location of 'Itivdlerk' is uncertain, but it may be the embayment Iterdlak $14 \mathrm{~km}$ east of Moriussaq, where black sands were found in our work. Various GGU reports have described the ilmenite sands and other possible commercial minerals (Ghisler \& Thomsen, 1971, 1972, 1973; Dawes, 1975, 1976a, personal communications).

The general geology of the area, and location of the principal prospects investigated are shown in Fig. 6. Analyses and evaluation of the samples and surveys are not yet complete, and the present conclusions are thus tentative.

\section{Field work}

The 1975 work was done during 30th August - 15th September. Because of heavy early snows it was possible to investigate only the ilmenite beach placers at North Star Bugt and Moriussaq (33 samples), and reported gold placers around Thule Air Base (four samples).

In 1977, work was done during 20th July and 6th September, mainly by boat transport hired from Avatak Henson of Moriussaq. About $1700 \mathrm{~km}$ were sailed, during which the accessible fjords between Savigsivik $\left(76^{\circ} \mathrm{N}\right)$ and Siorapaluk $\left(78^{\circ} \mathrm{N}\right)$ were inspected.

\section{Equipment and methods}

Ilmenite-bearing sands were sampled by 95 shovel-dug pits in nine localities on both active and uplifted beaches. Channel samples weighing 1 to $5 \mathrm{~kg}$ were taken along the pit sides. Pit depths varied up to about $1 \mathrm{~m}$, which was the maximum the shovel could conveniently reach; usually the bottom was shallower due to rocks or permafrost. Magnetic (Minimag) and electromagnetic (EM16) readings were taken at each sample site. The Minimag is made by the Norwegian Geological Survey and marketed by Atlas Copco, Abem: it measures both horizontal and vertical magnetic field components, and hand-held had an accuracy of \pm 50 gammas. The EM16, made by Geonics Ltd., uses VLF (very low frequency) radiation (c. $20 \mathrm{kHz}$ ) from a net of U.S. military transmitters, and measures the distortion in the vertical in-phase and out-of-phase components of the local electromagnetic (EM) fields due to any conductors, such as metal sulphide bodies. Its depth penetration under optimum conditions is about $150 \mathrm{~m}$. On the uplifted beaches, sampling traverses up to $1 \mathrm{~km}$ long were run from the shore to bedrock in the hinterland hills. Brunton and Silva 


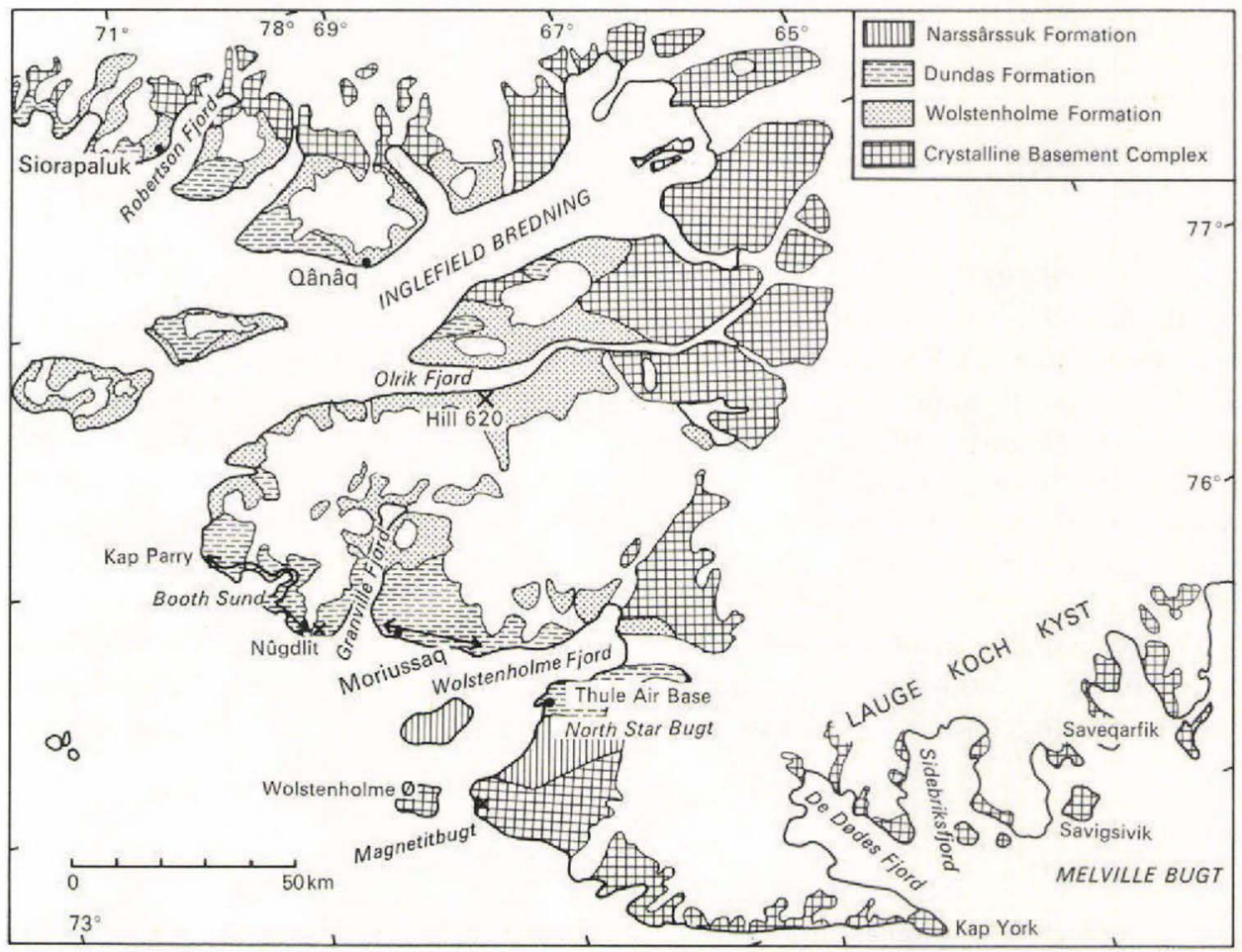

Fig. 6. Geological sketch map of the Thule district, showing the principal mineral sites prospected. Geology simplified from Dawes (1976b, fig. 223).

compasses, Thommen altimeters, and a Wild $25 \mathrm{~cm}$ optical-base range-finder were used for surveying the traverses. Special effort was made to sample the active beaches at low tide, to achieve the maximum data seaward.

Three copper prospects - Nûgdlit, Olrik Fjord and Naujat - were sampled, sketch-mapped and tested by EM16 surveys.

Iron at Magnetitbugt was sampled by six grab samples, sketched, and magnetic readings were made.

Gold was prospected at four localities by panning, and six samples were taken from three pyritic or limonitic outcrops for gold analysis.

Two specimens of seaweed (Fucus vesicularis?) were taken for heavy metals analysis.

Control traverses with the EM16 and Minimag were run across several large basic dykes, and 23 rock specimens were collected, mostly from Wolstenholme $\varnothing$ and Lauge Koch Kyst.

\section{Preliminary results}

\section{Titanium}

The Precambrian basic dykes and sills in the Thule region are ilmenite-bearing, and presumably are the principal source for the ilmenite beach sands. These sands usually 
bottom at less than $1 \mathrm{~m}$ depth in cobbles or permafrost. The minable tonnage therefore is assumed to be confined to this depth, though deeper sands in the permafrost zone might be exploitable. Probably at least 1 million tons of recoverable $\mathrm{TiO}_{2}$, or 5 million tons of grade $20 \% \mathrm{TiO}_{2}$, would be needed to start mining here (based largely on data from Lynd \& Leford, 1975). Although grades may reach much over $20 \% \mathrm{TiO}_{2}$, the known active beaches, about $10 \mathrm{~m}$ wide and say $1 \mathrm{~m}$ deep, are far too small to be mined. However, the older uplifted beaches, up to $1 \mathrm{~km}$ wide, could easily make commercial tonnage to $1 \mathrm{~m}$ depth, if grades were satisfactory. Our surveys therefore concentrated on the tracts of broad, uplifted beaches in the Moriussaq and Booth Sund regions. However, we carefully scouted all the shoreline along our whole trip, and sampled wherever the beaches appeared promising.

The principal field results are classified below.

(1) The old, uplifted beaches appear to have much less dark, heavy minerals than the active ones.

(2) The uplifted beaches vary abruptly from one to the next, from sandy to pebbly, cobbly, shingled or vegetated with humus; clean, sandy beaches are rare.

(3) The many run-off streams cutting across the beaches complicate sampling, as they redistribute the beach sands and heavy minerals across their wide, braided courses; swampy belts along old lagoons could not be sampled.

(4) Neither marked magnetic nor EM response was generally obtained over black sand beaches.

(5) Some black beaches are composed of black shale.

(6) The active thawed surface layer on the permafrost varies from 0.5 to $1^{+} \mathrm{m}$ depth, and probably averages about $1 \mathrm{~m}$; some of the sands continue into the permafrost.

(7) Some sandy beaches appear to extend seaward well below tide level, but these could not be usefully sampled with available equipment.

Moriussaq. The most promising beaches were found in the Moriussaq district, up to over 1 $\mathrm{km}$ wide along a $20 \mathrm{~km}$ stretch of coast. To $1 \mathrm{~m}$ depth, at least 20 million tons of sands would be available here.

Booth Sund. Much of the coast from Kap Parry to Nûgdlit is broad, uplifted beaches, with basic sills in the headlands and hinterlands being eroded to supply ilmenite. Many sampling traverses were made here, but the proportion of heavy black minerals appeared lower than at Moriussaq.

Granville Fjord and Robertson Fjord. Some beaches were also sampled here, but their ilmenite content appeared low.

Siorapaluk. Certain black sands here were not sampled, as they appeared due to oil spill. However, Peter Dawes (personal communication) reports that natural black sands do occur.

\section{Copper}

Traces of iron and copper sulphides are found in several places, as at Nûgdlît and Naujat, near contacts of the basic sills or dykes with dolomite or other beds of the Thule Group. Much stronger mineralisation occurs in sandstone near cross-cutting faults (Olrik Fjord, Hill $620)$. 
Olrik Fjord, Hill 620. Copper oxides occur here in moderately south-west-dipping sandstone of the Wolstenholme Formation, as disseminated grains or veinlets, probably replacing chalcopyrite. Just west of the prospect, a north-south fault cuts the Thule Group, and just south of it is a major east-west fault (Dawes, 1976b, figs 223 \& 231). The ore outcrop is largely covered by mineralised sandstone spalls, forming a conspicuous green tail downslope. The exposed portion of the mineralised sandstone is $3 \mathrm{~m}$ thick and extends over $100 \mathrm{~m}$ strike-length, but much more may be covered. The mineralisation was sampled by continuous chipping and mapped. No other copper mineralisation on strike, either to east or west, could be found. An EM16 traverse was run across the outcrop to test for sulphide response in depth.

Mineralisation may have risen along one of the nearby faults, and entered a permeable bed in the sandstone. The limited outcrop exposed would indicate only about 1500 tons of ore per metre vertical depth, but there may be much more. Clearly, the prospect should be investigated further, and it may warrant drilling.

Nûgdlit. Pyrite occurs here in dolomite of the Dundas Formation as pods distributed along the bedding, and as disseminated cubes. The pods are a few centimetres in size, and carry traces of copper sulphides, which have oxidised to stain the cliff face green. The sulphides probably were introduced by a nearby basic sill. They were sampled and sketch-mapped, but the copper is much too sparse for mining.

Naujat. At this locality, a swarm of large, west-north-west striking, steep-dipping basic dykes cut flattish shales of the Dundas Formation. Veinlets and pods of $\mathrm{Fe}$ and $\mathrm{Cu}$ sulphides occur in the dykes and in adjacent shale, staining the cliffs green. The prospect was sampled and sketch-mapped, but appears to have no commercial possibilities.

Iron

Magnetitbugt - Wolstenholme $\emptyset$. Banded iron ore was reported by Davies et al. (1963) on Wolstenholme $\varnothing$ and on the adjacent mainland. We circumnavigated the island and made several traverses inland, but failed to locate it. However, Dawes (1975; written communication, 1975) reported massive magnetite float at Magnetitbugt, and this was located. Its source was traced to near the top of the cliff back of the bay. Here, several conformable massive magnetite bands up to $3+\mathrm{m}$ thick occur in the folded gneiss, with an exposed strike length of $200 \mathrm{~m}$, dipping flatly west. The magnetite was mapped and sampled and magnetometer readings made. Grades are probably good, but the tonnage indicated at this locality is far too low for mining.

Lauge Koch Kyst. Dawes (1975, 1976a, personal communication) has mapped iron-bearing schists on the inland areas east of Kap York at various localities. We proposed to check the near coastal localities from the boat, but found that the principal access, by $\mathrm{De}$ Dødes Fjord and Sidebriksfjord, was blocked by sea ice, while icebergs blocked access to Saveqarfik. We reconnoitered the accessible parts of the coast, took samples and observations, but located no interesting mineralisation.

Gold

Siorqap kûa. Following rumours of placer gold mining in 'Fox Canyon' on Thule Air Base, the upper and lower course of the stream Siorqap kûa, was panned for gold. However, only 
two very small gold colours were obtained from about 50 pans. The heavy black tails were saved for analysis. Panning at other sites was planned, but prevented by unfavourable weather.

Pyrite

Moriussaq. On the west side of the bay at Moriussaq, pockets of massive pyrite and magnetite-ilmenite occur in folded dolomite and shales of the Dundas Formation along $50 \mathrm{~m}$ strike. The mineralisation probably is derived from a basic sill which underlies the dolomite. The ilmenite doubtless is a major contributor to the Moriussaq beach sands.

On a beach scarp about $700 \mathrm{~m}$ south-east of Moriussaq, a little coarse pyrite, up to 1-2 cm size, occurs in veinlets and pods along joints and fractures in iron-stained dolomite. Specimens have been recovered by Moriussaq inhabitants, as well as by Dawes (personal communication, 1975). The pyrite crystals might obtain some acceptance by Greenlanders for lapidary work.

\section{Tentative conclusions and recommendations}

The following conclusions are based on the field work, modifiable by pending laboratory and office studies.

(1) Commercial possibilities for the ilmenite beach sands depend on the grade and tonnage in the uplifted beaches. If our sampling gives favourable results then,

(a) the permafrost zone should be test-sampled by drilling,

(b) the adjacent offshore beaches should be sampled from a boat,

(c) the Siorapaluk black sand beach should be investigated,

(d) the ilmenite sands north of Siorapaluk should be investigated.

Their presumed source, the basic dykes and sills, continues into Peary Land (Dawes, 1976b).

(2) The Olrik Fjord, Hill 620 copper should be further investigated, and possibly drilled.

(3) The iron formation along Lauge Koch Kyst should be examined with helicopter support.

(4) The untested gold placer site on Siorqap kûa should be panned.

(5) The Proterozoic carbonate rocks in Inglefield Land, $78^{\circ}$ to $79^{\circ} 30^{\prime} \mathrm{N}$, should be examined for possible lead-zinc mineralisation.

\section{Acknowledgements}

Erik Arnholtz (Thule Air Base) is thanked for providing an invaluable radio link with the field activities and for other general help. Able field assistance was received from Kurt Thomsen and Gunnar Ersgaard. Peter Dawes originally suggested this investigation, and has contributed greatly to all phases of it. 


\section{References}

Davies, W. E., Krinsley, D. B. \& Nicol, A. H. 1963: Geology of the North Star Bugt area, Northwest Greenland. Meddr Grønland 163, 12, 68 pp.

Dawes, P. R. 1975: Reconnaissance of the Thule Group and underlying basement rocks between Inglefield Bredning and Melville Bugt, western North Greenland. Rapp. Grønlands geol. Unders. 75, 34-38.

Dawes, P. R. 1976a: 1:500 000 mapping of the Thule district, North-West Greenland. Rapp. Grønlands geol. Unders. 80, 23-28.

Dawes, P. R. 1976b: Precambrian to Tertiary of northern Greenland. In Escher, A. \& Watt, W. S. (edit.) Geology of Greenland, 248-303. Copenhagen: Geol. Surv. Greenland.

Ghisler, M. \& Thomsen, B. 1971: The possibility of ilmenite placers in the Thule district, North Greenland. Rapp. Grønlands geol. Unders. 43, 15 pp.

Ghisler, M. \& Thomsen, B. 1972: Short note on the ilmenite sands from the Thule district, North Greenland. Grønlands geol. Unders. Int. unpubl. rep., 2 pp.

Ghisler, M. \& Thomsen, B. 1973: Nyt vidnesbyrd om forekomster af ilmenitsand i Thule distrikt, Nordgrønland. Grønlands geol. Unders. Int. unpubl. rep., 3 pp.

Koch, L. 1920: Stratigraphy of Northwest Greenland. Meddr dansk geol. Foren. 5, 17, 78 pp.

Lynd, L. E. \& Leford, S. J. 1975: Titanium. In Industrial Minerals and Rocks, 1149-1208. New York: Amer. Inst. of Mining, Metal. and Petrol. Eng. 